Криштопа С.І., Криштопа Л.І., Микитій I.М., Гнип М.М., Козак Ф.В.

Івано-Франківській начіональний технічний університет нафти і газу

\title{
ЕКСПЕРИМЕНТАЛЬНІ ДОСЛІДЖЕННЯ ЗНИЖЕННЯ ВТРАТ ЕНЕРГІЇ В АГРЕГАТАХ ТРАНСМІСІЇ ПІДЙОМНИХ УСТАНОВОК ДЛЯ РЕМОНТУ СВЕРДЛОВИН
}

\begin{abstract}
Стаття спрямована на вирішення проблеми зниження втрат енергії в трансмісійних агрегатах підйомних установок для ремонту свердловин. Були проаналізовані основні напрямки 3 скорочення енергоспоживання підйомних установок для ремонту свердловин. Проведений аналіз особливостей конструкції трансмісій підйомних установок для ремонту свердловин. Виконані дослідження в'язкіснотемпературних характеристик сучасних трансмісійних олив та температурного режиму в трансмісійних агрегатах. Був запропонований метод швидкого прогріву та підтримання оптимального температурного режиму в трансмісійних агрегатах підйомних установок за рахунок використання теплоти відпрацьованих газів. Досліджена типова механічна трансмісія підйомної установки для ремонту свердловин на колісному шасі. Наведена методика та засоби експериментальних досліджень енергоефективності трансмісій підйомних установок. Виконані експериментальні дослідження реалізації запропонованого методу зниження втрат енергії в трансмісійних агрегатах. Встановлена залежність зміни температури трансмісійної оливи в коробці перемикання передач при різних режимах обертання первинного валу коробки передач. Одержана залежність втрат потужності в коробці перемикання передач підйомної установки моделі УПА 60/80А в залежності від температури та сорту трансмісійної оливи. Наведені результати розрахунків перевитрат палива в коробці перемикання передач підйомної установки моделі УПА 60/80А з різними силовими приводами та за різних температур трансмісійної оливи.

Ключові слова: підйомна установка для ремонту свердловин, нафтогазовий технологічний транспорт; дизельний двигун; трансмісійний агрегат; коробка перемикання передач; утилізація теплоти; відпрацьовані гази; потужність; питома витрата палива.
\end{abstract}

\section{ВСТУП}

Нафтогазова галузь, поряд 3 іншими структурами, включає у себе численні виробничі підрозділи технологічного транспорту. Призначення нафтогазового технологічного транспорту забезпечення неперервної роботи основного виробництва виконанням технологічних операцій та транспортної роботи в заданих обсягах та заданий час. Нафтогазовий технологічний транспорт об'єднує в собі значну номенклатуру установок: для буріння і ремонту свердловин; для гідравлічного розриву пластів, промивні та піскозмішувальні установки; цементувальні та цементозмішувальні агрегати; пересувні компресорні; парогенераторні; для обслуговування та ремонту нафтогазопромислового обладнання; для ремонту та будівництва газонафтопроводів; для налагоджування та монтажу нафтогазопромислового обладнання, змащування верстатів-гойдалок; для підігріву та депарафінізації свердловин; для механізації робіт; для геофізичного дослідження свердловин та багато інших типів та моделей. За своєю чисельністю нафтогазовий технологічний транспорт переважаю всі інші види технологічного транспорту інших галузей. Тому на особливу увагу заслуговує проблема зниження витрат енергії для нафтогазового технологічного транспорту, зокрема зниження витрат енергії в трансмісіях підйомних установок.

\section{АНАЛІЗ ЛІТЕРАТУРНИХ ДАНИХ ТА ПОСТАНОВКА ПРОБЛЕМИ}

Питання покращення енергоефективності - один із головних пріоритетів України. У 2017 році в Украйні було затверджено «Нову Енергетичну стратегію України до 2035 року: безпека, енергоефективність, конкурентоспроможність» - це головний документ, який визначає стратегічні орієнтири розвитку паливно-енергетичного комплексу держави на період до 2035 р. Відповідно до цього нормативного акту передбачається, що частка імпортних компонентів в структурі загального первинного постачання енергії країни знизиться у 2025-2035 рр. до менш ніж 33 \%, зокрема завдяки підвищенню енергоефективності та енергозбереженню 3 дотриманням сучасних екологічних стандартів та широкому розвитку відновлювальних енергоджерел. Нова енергетична стратегія держави містить три основних етапи, головним результатом яких має бути зменшення енергоємності ВВП до 2035 року порівняно з поточним значенням більше, ніж у вдвічі [1]. Також слід відмітити, що наша держава, як член Енергетичного європейського співтовариства, імплементувала Директиву Євросоюзу 2009/28/ЕС щодо просування відновлюваної енергетики і передбачила в 2020 році введення обов'язкової частки відновлюваної енергії у структурі загального споживання країни на рівні $11 \%[2]$.

Для досягнення поставлених державною енергетичною політикою завдань необхідно максимально знижувати енергоспоживання всіх об’єктів та обладнання, в т.ч. i тих, які експлуатуються в нафтовій і газовій промисловості України. Це повною мірою стосується як в цілому нафтогазового технологічного транспорту, так і також такої важливої його складової, як підйомні установки для ремонту свердловин. Зазначені установки мають малоекономічні, у порівнянні 3 електроприводом, дизельні силові приводи з механічними трансмісіями, що вимагає, в т. ч., і пошуку нових напрямків покращення паливно-економічних характеристик силових приводів підйомних установок [3]. 
Витрати на функціонування технологічного транспорту становлять значну частку в собівартості п укції нафтогазової галузі, тому зменшення споживання енергії та собівартості технологічних робіт під час експлуатації силових приводів підйомних установок для ремонту свердловин - актуальне завдання для фахівців нафтогазової промисловості [4]. Основними напрямками 3 скорочення енергоспоживання підйомних установок для ремонту свердловин, які досліджуються в даній роботі є:

- ефективне використання надлишкової теплоти робочого процесу; трансмісії.

- забезпечення швидкого прогрівання та підтримання оптимального температурного режиму

Для, виконання складних робіт з капітального ремонту глибоких свердловин використовуються підйомні установки великої потужності і вишки, що дозволяє виконувати спуско-піднімальні операції 3 бурильними й обсадними трубами. Комплекс такого устаткування перетворюється в мобільну бурову установку. Таким чином, на базі невеликого числа уніфікованих вузлів будуються конструкції підйомних установок різних призначень і параметрів [5].

Мобільні установки для ремонту свердловин функціонально являють собою систему 3 одного (частіше всього) чи двох приводних двигунів i трансмісії - перетворювача, що передає i трансформує енергію обертання вала двигуна в енергію гака, що переміщається поступально. Мінімально необхідна кратність регулювання частоти обертання і моментів на валу лебідки підйомників для виконання ними спуско-поднімальних і технологічних операцій знаходиться в межах приблизно 1:4. Із зовнішньої характеристики ДВ3 випливає, що крутний момент, змінюється в меншому інтервалі. У зв'язку з цим виникає необхідність застосування в трансмісії механічних, гід инамічних чи комбінованих перетворювачів [6].

Дослідження ряду авторів [7,8 та ін.] показали, що температурний режим механічних трансмісій в умовах негативних температур не досягає оптимальних значень робочих температури трансмісійних агрегатів навіть після трьох годин роботи на різних навантажувальних режимах.

Згідно $з$ дослідженнями [9, 10 та ін.], втрати потужності в трансмісії безпосередньо залежать від iї температурного режиму роботи, тому що в'язкість трансмісійного масла збільшується 3 пониженням температури навколишнього середовища. Сучасні оливи характеризуються різними як експлуатаційними, так і в'язкісно-температурними властивостями. Відповідно до результатів досліджень [9], в'язкість мінеральної трансмісійної оливи 80W-90 істотно змінюється вже при температурі нижче $+10{ }^{\circ} \mathrm{C}$, при температурах мінус $25 \ldots 30{ }^{\circ} \mathrm{C}$ вона досягає застигання. За представленими дослідженнями зроблено висновок, що при зниженні температури навколишнього повітря в зимовий період експлуатації, внаслідок зменшення середньої температури оливи, їі в'язкість в агрегатах значно вище оптимальних значень, що обумовило підвищений знос шестерень.

При дослідженні теплових режимів роботи агрегатів трансмісії автомобілів при експлуатації в умовах від'ємних температур було встановлено, що на величину середньої температури оливи агрегатів значний вплив робить режим роботи автомобіля та швидкість і напрямок повітря, що обдуває автомобіль. При роботі автомобіля за температури навколишнього середовища мінус $20{ }^{\circ} \mathrm{C}$ iз зупинками, сумарна тривалість яких дорівнює загальному часу руху, зниження середньої температури в коробці перемикання передач складає $19^{\circ} \mathrm{C}$, а в роздавальної коробці на $13^{\circ} \mathrm{C}$ [11]. На підставі цього можна зробити висновок, що режим руху із зупинками має істотне значення при розгляді теплового режиму трансмісії при іï роботі в умовах негативних температур.

Дослідження пристосованості автомобілів ГАЗ-66, ЗІЛ-131 і ін. за тепловим режимом агрегатів показали, що при температурі навколишнього повітря мінус $40{ }^{\circ} \mathrm{C}$ температура оливи в картері коробок перемикання передач має значення від 2 до $33^{\circ} \mathrm{C}$ [12].

Оптимальний тепловий режим роботи агрегатів механічної трансмісії підйомних установок заводом-виробником не встановлюється в жорстких рамках. Визначальним фактором $\epsilon$ працездатність оливи при певних умовах. Так, наприклад, встановлена максимальна температура трансмісійної оливи ТСп-15К, яка в агрегатах трансмісії автомобілів підйомних установок УПА-60/80 не повинна перевищувати $120^{\circ} \mathrm{C}$ [13]. Мінімальне обмеження задається в'язкісно-температурною характеристикою застосовуваної оливи (не нижче мінус $30^{\circ} \mathrm{C}$ ). За даними авторів [14], оптимальна температура оливи 3 індексом в'язкості 80W-90 в картері коробки перемикання передач підйомної установки УРБ-2А2 на шасі автомобіля Урал-4320, 3 точки зору мінімізації втрат енергії, складає 30 ${ }^{\circ} \mathrm{C}$.

\section{ЦІЛ ТА ЗАДАЧІ ДОСЛІДЖЕННЯ}

Витрати на функціонування технологічного транспорту становлять значну частку в собівартості п укції нафтогазової галузі, тому зменшення споживання енергії та собівартості технологічних робіт під час експлуатації силових приводів підйомних установок для ремонту свердловин - актуальна проблема для фахівців нафтогазової промисловості.

Тому метою даної статті $є$ встановлення в лабораторних умовах основних закономірностей зміни енергетичних та потужнісних характеристик трансмісій підйомних установок для ремонту свердловин нафтогазової галузі при реалізації запропонованих енергоефективних рішень. Відповідно до мети програма досліджень містить такі задачі: експериментальні дослідження енергетичних витрат в трансмісіях існуючих підйомних установок для ремонту свердловин; експериментальні дослідження енергетичних витрат в трансмісіях удосконалених підйомних установок для ремонту 
свердловин 3 пропонованою високоефективного системою підігріву трансмісійних агрегатів відпрацьованими газами.

\section{РЕЗУЛЬТАТИ ДОСЛІДЖЕНЬ \\ Типова схема трансмісій}

Особливості конструкції підйомних установок визначаються глибиною свердловини, змістом операцій, дорожньо-кліматичними умовами. Умови експлуатації устаткування для ремонтів свердловин ускладнюються низькими або високими температурами навколишнього середовища, станом або наявністю мережі доріг та ін. Ці умови покладені в основу конструювання і виготовлення устаткування, причому особливо жорсткі вимоги до конструкції устаткування для найбільш мобільного процесу - поточного ремонту свердловин. Мобільність процесу ремонту свердловин i складні дорожньо-кліматичні умови в основних районах видобутку нафти і газу в Україні, Свропі та світі визначають головну вимогу до устаткування для цього процесу - його високу транспортабельність.

Транспортування устаткування в літній період в межах України або Свропи не представляють складної проблеми, тому що може забезпечуватися звичайними колісними транспортними базами. Транспортування устаткування в умовах сніжної зими, весняного чи осіннього бездоріжжя, традиційно забезпечувалось транспортними базами високої прохідності на гусеничному ходу. Однак досвід останніх років показав, що прохідність таких агрегатів, незважаючи на гусеничну базу, мало чим відрізняється від прохідності агрегатів на колісному ходу, а іноді і гірше їх, тому що гусеничний транспортер-трактор зберігає високу прохідність, лише коли несе на собі невелике навантаження, значно менше маси агрегатованого на ньому устаткування. Крім того, гусеничні транспортери руйнують дорожнє покриття, мають невисокі швидкості пересування. Тому оптимальною транспортною базою агрегатів для ремонту свердловин не великої вантажопідйомності є стандартний автомобіль високої прохідності, наприклад типу автомобіля КрАЗ із трьома ведучими мостами, шинами з можливістю регулювання тиску і достатньо потужним двигуном. Автомобілі цього класу мають достатні прохідність, вантажопідйомність і швидкості пересування.

Як трансмісії та перетворювачі потужності для підйомних установок ремонту свердловин виробництва України, колишнього СНД та закордонного виробництва невеликої вантажопідйомності переважно застосовуються механічні коробки швидкостей, у більшості випадків шестеренчасті, рідше ланцюгові зі ступеневим регулюванням частоти обертання. Типова механічна трансмісія підйомної установки для ремонту свердловин на колісному шасі (УПА 60А 60/80) - наведена на рис. 1.

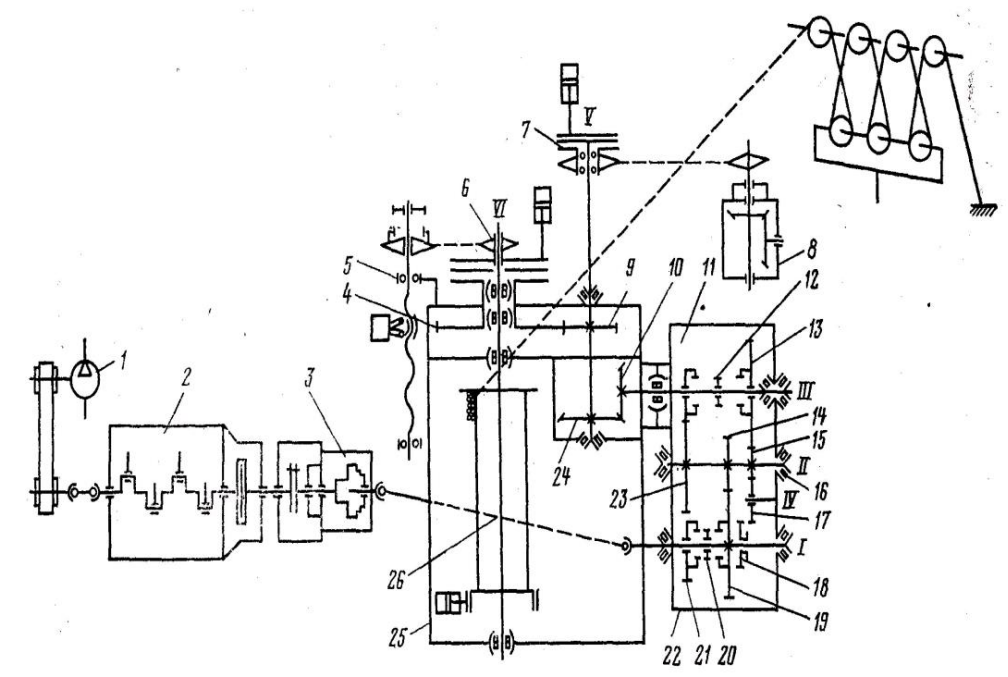

1 - компресор; 2 - двигун; 3 - коробка відбору потужності; 4, 9 - шестерні передачі обертання барабанному валу; 5 - талевий блок; 6 - фрикційна муфта; 7 - фрикційна муфта дискова; 8 реверсивний редуктор; 10, 24 - шестерні конічні; 11 - шестерня 3-ї і 4-ї швидкостей; 12 - муфта; 13 шестерня 1-ї та 2-ї швидкостей; 14, 16, 23 - шестерні проміжного вала; 15 - роликові підшипники; 17, 18 - шестерні оберненого обертання барабана; 19 - шестерня 2-ї та 4-ї швидкостей; 20 - муфта; 11 шестерні 1-ї и 3-ї швидкостей; 22 - корпус коробки передач; 25 - лебідковий блок: 26 - карданний вал; - ведучий вал; II - проміжні вали; Ш - ведений вал: VI - вісь

Рисунок 1 - Типова механічна трансмісія підйомної установки для ремонту свердловин УПА 60А 60/80 на колісному шасі КрАЗ

На автомобільній або тракторній транспортній базі часто використовується як перетворювач крутного моменту від двигуна власно штатну коробку перемикання передач самої транспортної бази. Трансмісія установки для ремонту свердловин складається зі сукупності муфт, валів, ланцюгових передач, лебідки і поліспаста, з'єднаного з гакоблоком. Поліспаст із гаком і блоками, називається талевою системою, яка розміщується на вишці підйомної установки. Число швидкостей і їхнє співвідношення визначаються в залежності від технології спуско-поднімальних операцій. Така схема 
підйомної установки, побудована на механічних трансмісіях, у даний час $є$ найбільш поширена в Україні.

Планування експериментальних досліджень

Мета і задачі експериментальних досліджень характеристик підйомних установок для ремонту свердловин визначили вибір необхідного устаткування, вимірювального обладнання і апаратури та об'єктів для випробувань.

Завданням експериментальних досліджень $є$ визначення основних закономірностей енерговитрат штатних трансмісій існуючих підйомних установок та удосконаленої трансмісії 3 пропонованою системою підігріву трансмісійних агрегатів відпрацьованими газами двигуна. При цьому доцільним $є$ визначення в результаті експериментальних досліджень відповідних систем параметрів, що визначають показники енерговитрат. Вирішенням цього завдання $\epsilon$ реалізація багатофакторного експерименту з відтворенням основних умов протікання досліджуваних процесів.

Складання плану експериментальних досліджень відповідно до положень теорії планування експериментів створює умови для збільшення достовірності результатів вимірювань і в багатьох випадках істотне скорочення обсягу експериментальних досліджень та/або стендових випробувань. Але успішне застосування сучасних методів планувань експериментальних досліджень (для прикладу - складання факторних планів) передбачає обов'язкову наявність певного мінімуму відомостей щодо зв'язків між досліджуваними факторами.

Аналіз літературних джерел з даної проблеми показав, що поки немає достовірних відомостей щодо енерговитрат трансмісій підйомних установок для ремонту свердловин нафтогазової галузі. Можна тільки стверджувати, що на показники енерговитрат трансмісій підйомних установок для ремонту свердловин впливають температури навколишнього середовища та агрегатів трансмісії. Але факторні плани гарантують отримання в результаті мінімальної кількості досліджень достовірних значень коефіцієнтів в рівняннях регресій тільки за відомих до початку експериментів порядку регресивного рівняння. Більше того, проведення експериментальних досліджень 3 використанням факторних планів можливо тільки за достатньо конкретних теоретичних уявлень про досліджувані процеси.

При плануванні досліджень були встановлені наступні завдання:

- створити читки умови для оцінювання випадкових похибок вимірювань;

- забезпечити мінімальні величини для систематичних помилок і виключити грубі помилки;

- забезпечити адекватності відтворення параметрів експериментів від дослідження $\mathrm{i}$ до дослідження;

- забезпечення мінімальних відхилень параметрів, що характеризують умови експериментів (вологість, тиск і температури в експериментальних установках).

Методика експериментальних досліджень

Експериментальна перевірка розроблених теоретичних положень проводилися в умовах лабораторії теплових двигунів кафедри автомобільного транспорту Івано-Франківського національного технічного університету нафти і газу на базі силового приводу дизельного двигуна Д21A1 (рис. 2), що включає в себе вимірювальну апаратуру та коробку перемикання передач, встановлену на стенді. 3 огляду на те, що механічна трансмісія має фізичну, геометричну і теплову подібність, отримані результати досліджень можуть бути поширені на коробки передач автомобілів та підйомних установок.

Реєстрація даних, необхідних для визначення теплового режиму коробки перемикання передач під впливом низької температури проводилася в умовах тієї ж лабораторії на експериментальній установці на базі мобільного кондиціонера Електролюкс.

Для реєстрації температури відпрацьованих газів та трансмісійної оливи використовувався вимірювальний комплекс на базі персонального комп'ютера, восьмиканального мотор-тестера та хромель-копелєвих термопар. Один з датчиків встановлювався на виході з випускного колектора (до рекуператора), інший - в агрегатах трансмісії, занурений в оливу. При цьому чутливі елементи датчиків температури (хромель-копель) розташовувалися по центру перетину труби випуску відпрацьованих газів. Покази датчиків температури відпрацьованих газів та трансмісійної оливи реєструвалися неперервно. Реєстрація температури відпрацьованих газів відбувалась за допомогою термопар хромель-копель 3 межею відхилення $\pm 2{ }^{\circ} \mathrm{C}$ в інтервалі вимірюваних температур від мінус 20 до плюс $380{ }^{\circ} \mathrm{C}$. Вимірювання температури оливи в картері коробки передач і навколишнього повітря відбувалося за допомогою термоперетворювачів опору, що мають допустиме відхилення значень температури $\pm 0,2^{\circ} \mathrm{C}$. 


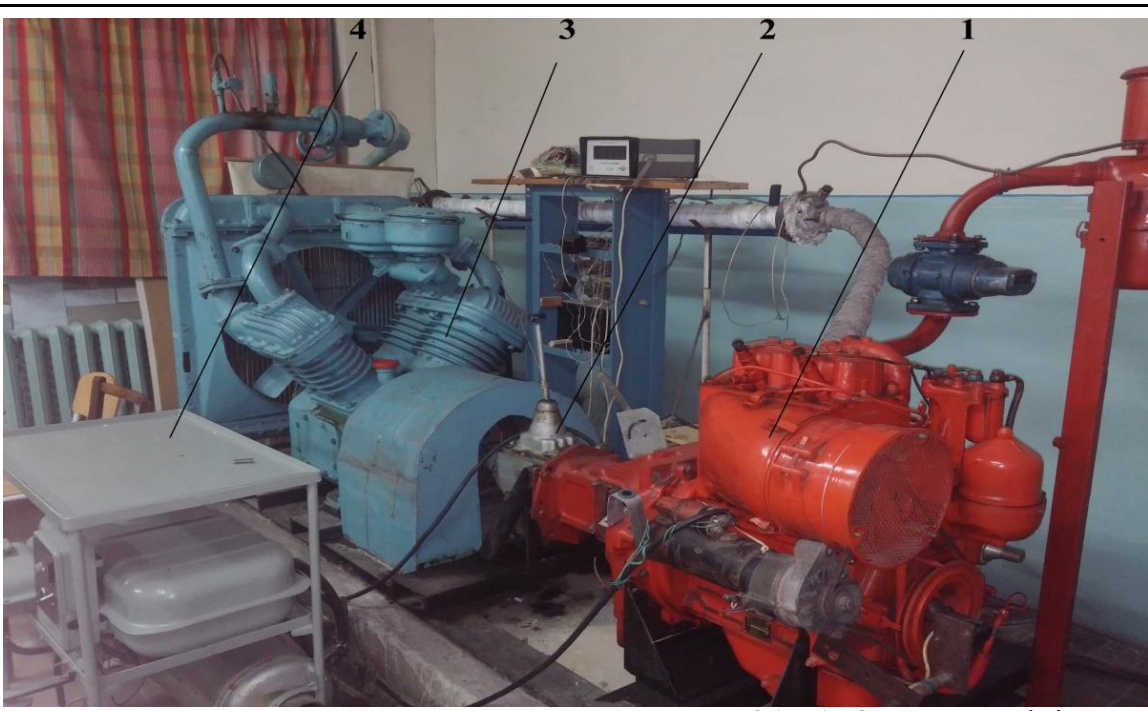

1 - конвертований на дизельний двигун Д21А1; 2 - трансмісія;

3 - компресор К-5М; 4 - пристрій підігріву повітря

Рисунок 2 - Зовнішній вигляд експериментального стенду на базі дизельного двигуна Д21А1

Для дослідження температури трансмісійної оливи в картер коробки перемикання передач були встановлені два термодатчика. Датчик № 1 встановлювався в нижньому шарі відділу шестерень першої передачі і заднього ходу, датчик № 2 - у верхньому шарі масла близько шестерень 5-й передачі.

Привід первинного вала коробки передач здійснювався від дизельного двигуна Д21А1. Колінчастий вал дизельного двигуна обертався за допомогою електричного двигуна постійного струму. Для цього штатний стартер дизельного двигуна Д21А1 був замінений на спеціальний редукторний електродвигун постійного струму. Живлення електродвигуна відбувалося від блока живлення на 14 В та 500 А.

Вимірювання втрат потужності в коробці перемикання передач відбувалося за допомогою вимірювання напруги та сили струму на привідному електродвигуні. Втрати потужності в коробці перемикання передач вираховували за формулою

$$
N_{\kappa n}=U_{\partial в+\kappa n} \cdot I_{\partial \beta+\kappa n}-U_{\partial \varepsilon} \cdot I_{\partial \varepsilon}, \mathrm{Bт},
$$

де $U_{\partial \beta+\kappa n}$ - напруга, що падає на привідному електродвигуні при прокручування дизельного двигуна з приєднаною через зчеплення коробкою перемикання передач, В;

$I_{\partial \ell+\kappa n}$ - сила струму, що споживається на привідному електродвигуні при прокручування дизельного двигуна з приєднаною через зчеплення коробкою перемикання передач, А;

$U_{\partial в}$ - напруга, що падає на привідному електродвигуні при прокручування дизельного двигуна 3 від'єднанню через зчеплення коробкою перемикання передач, В;

$I_{\partial в}$ - сила струму, що споживається на привідному електродвигуні при прокручування дизельного двигуна з від'єднанню через зчеплення коробкою перемикання передач, А.

Вибір параметру оптимізації здійснювався на підставі завдань досліджень, відповідно до яких необхідно отримати експериментальні дані про сукупний вплив ряду факторів (швидкості обертання шестерень, час роботи коробки передач, температури навколишнього повітря, технічного стану агрегату трансмісії, в'язкості масла, геометричних розмірів та ін.) на втрати потужності коробки передач.

В якості основних досліджуваних параметрів були обрані температура оливи в трансмісійному агрегаті, температура навколишнього повітря, температура відпрацьованих газів, час роботи агрегатів, частота обертання первинного валу агрегату, які задовольняє всім необхідним вимогам: кількісної мірою оцінки; однозначністю кількісного оцінювання; ефективністю в статистичному сенсі, тобто визначення 3 високою точністю; доступності вимірювання та універсальності; однозначності при всіх станах досліджуваного об'єкта. В якості інших чинників були обрані: сорт масла, технічний стан коробки передач та ін., які підтримувалися на постійному рівні.

Для експериментального підтвердження можливості реалізації пропонованих заходів 3 скорочення часу нагрівання оливи масла в коробці передач підйомної установки при роботі двигуна в процесі експерименту реєструвалися поточні значення наступних параметрів: температура відпрацьованих газів двигуна; температура оливи в картері коробки передач; температура навколишнього середовища; час роботи двигуна без та спільно з системою теплопостачання. установок

Засоби експериментальних досліджень енергоефективності трансмісій підйомних 
Стендові дослідження проводились на експериментальній установці, що включала в себе серійний дизельний двигун Д21А1 та серійну коробку передач від автомобіля ЗіЛ-130 моделі 1301700010-10. В табл. 1 наведена коротка технічна характеристика двигуна Д21А1. Схема дослідної установки на базі дизельного двигуна Д21А1 зображена на рис. 2.

Таблиця 1 - Основна технічна характеристика експериментального конвертованого двигуна Д21А1

\begin{tabular}{|c|c|c|c|}
\hline $\begin{array}{l}\text { № } \\
\Pi / \Pi\end{array}$ & Назва параметрів двигуна & $\begin{array}{c}\text { Одиниця ви- } \\
\text { мірювання }\end{array}$ & Значення \\
\hline 1 & Тип двигуна & - & $\begin{array}{l}\text { Двохциліндровий, дизельний, чотирьох- } \\
\text { тактний, } 3 \text { повітряним охолодженням }\end{array}$ \\
\hline 2 & Робочий об’єм двигуна & л & 2,080 \\
\hline 3 & Маса двигуна & КГ & 283 \\
\hline 4 & $\begin{array}{l}\text { Спосіб сумішоутворення базового } \\
\text { двигуна }\end{array}$ & - & $\begin{array}{c}\text { Впорскуванням дизельного палива, } 3 \\
\text { нероздільною камерою згорання }\end{array}$ \\
\hline 5 & $\begin{array}{l}\text { Спосіб сумішоутворення } \\
\text { конвертованого двигуна }\end{array}$ & - & $\begin{array}{c}\text { Впорскуванням паливної суміші, } \\
\text { нероздільна камера згорання }\end{array}$ \\
\hline 6 & Номінальна потужність двигуна & кВт (к.с.) & $18(25)$ \\
\hline 7 & Ефективна питома витрата палива & $\begin{array}{l}\Gamma / \text { КВтгод } \\
(\text { г/к.с.год) }\end{array}$ & $\begin{array}{c}253 \\
(186) \\
\end{array}$ \\
\hline 8 & $\begin{array}{l}\text { Частота обертання колінчастого } \\
\text { вала двигуна, за номінальної } \\
\text { потужності }\end{array}$ & об./хв. & $1775-1825$ \\
\hline 9 & $\begin{array}{l}\text { Частота обертання колінчастого } \\
\text { вала двигуна на оборотах холостого } \\
\text { ходу }\end{array}$ & об./хв. & $775-825$ \\
\hline 10 & Коробка перемикання передач & - & $130-1700010-10$ \\
\hline 11 & Передавальні відношення КПП & - & $\begin{array}{l}\text { I-6,45; II-3,56; III-1,98; IV-1,275; V-1,00; } \\
\text { 3X-7,09 }\end{array}$ \\
\hline 12 & Мaca КПП & КГ & 115 \\
\hline
\end{tabular}

Навантаження для експериментального двигуна Д21А1 (рис. 3, поз. 5) створюється за допомогою чотирьохступінчатого чотирьохциліндрового повітряного компресора моделі К-5М (рис. 3, поз. 9). Потужність на колінчастому валу компресора К-5М може регулюватись в діапазоні $1 \ldots 30$ кВт, що дозволяло на $100 \%$ навантажувати експериментальний конвертований двигун та коробку перемикання передач. Крутний момент від конвертованого двигуна Д21А1 до компресора передавався за допомогою карданної передачі (рис. 3, поз. 7) та коробки перемикання передач моделі 130-1700010-10 (рис. 3, поз. 6).

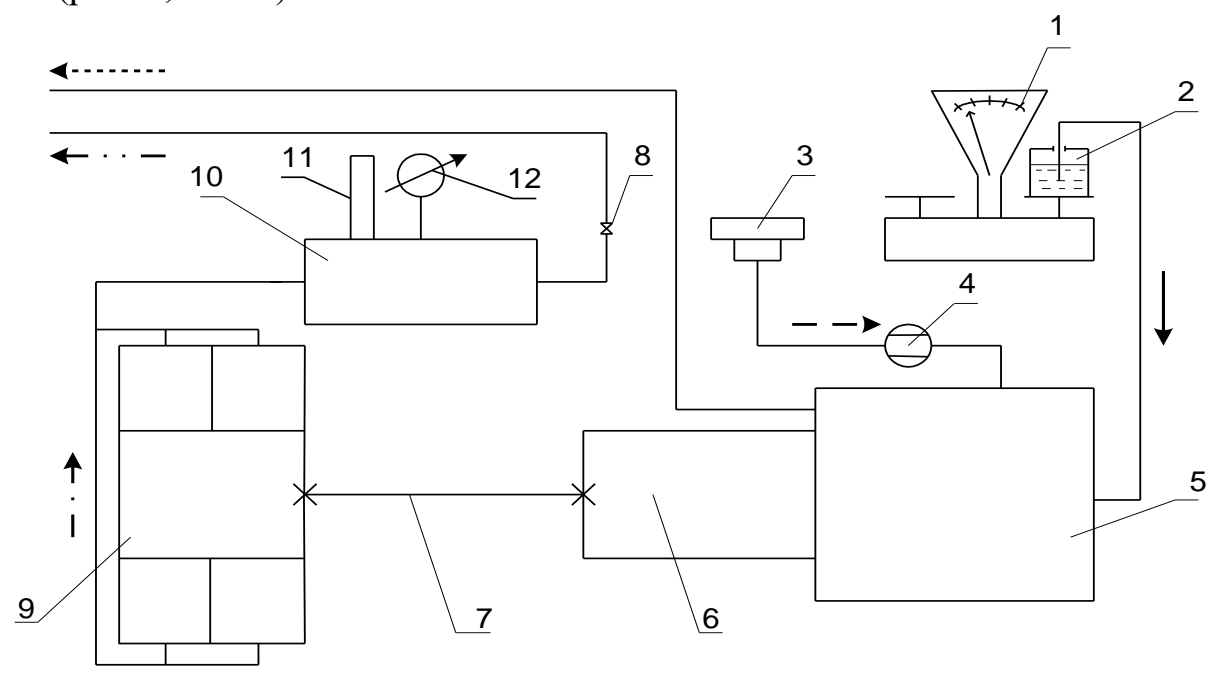

$\longrightarrow$ - напрямки руху палива в системі живлення дослідної установки; $\rightarrow-\longrightarrow$ - напрямки руху повітря в системі живлення дослідної установки; - - - - рух повітря від компресора до ресивера; 4--.--.- - рух відпрацьованих газів двигуна на КПП та в навколишнє середовище; $\leftarrow \cdots-$ - рух повітря з ресивера в навколишнє середовище; 1 - вага вимірювання витрати палива; 2 - ємність для альтернативного палива; 3 - фільтр очищення повітря; 4 - лічильник газовий; 5 - експериментальний спиртогазовий двигун; 6 - коробка перемикання передач; 7 - карданна передача; 8 - дросельний патрубок; 9 - навантаження (компресор); 10 - ресивер; 11 - термометр вимірювання температури навколишнього середовища; 12 - манометр газовий.

Рисунок 3 - Схема експериментальної установки на базі дизельного двигуна Д21А1 
Дизельний двигун Д21А1 було переобладнано для роботи на альтернативній спиртогазовій суміші. Для цього $з$ головок блоку були демонтовані штатні дизельні форсунки, нарізана додаткова різьба M14x1,25 в каналах розпилювачів форсунок та встановлені свічки запалення. Конструкція головок двигуна перероблена таким чином, що замість свічки запалення легко вкрутити назад дизельну форсунку. Конвертований таким чином двигун дозволяє за час близько 10 хвилин переходити на різні види палива, міняючи місцями свічки запалення та дизельні форсунки. Переобладнані з дизельного палива на газове головки блока двигуна Д21А1 показані на рис. 4.

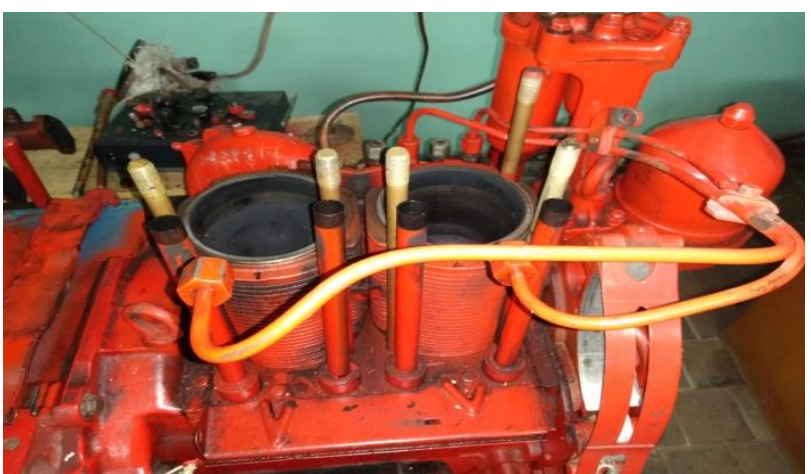

a)

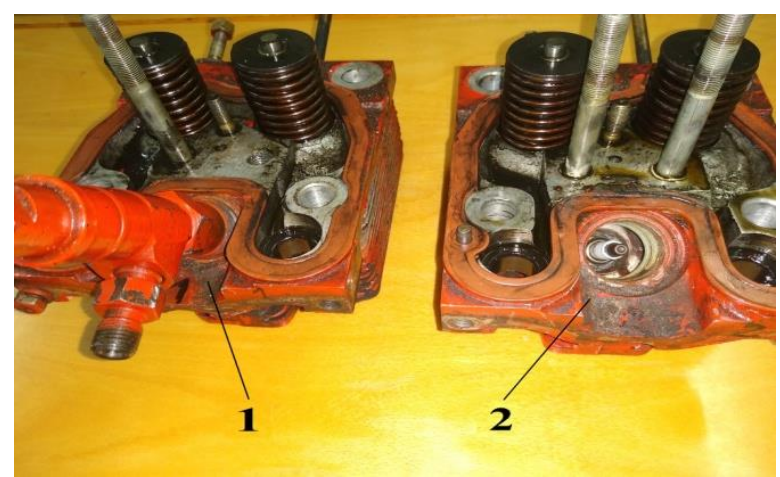

б)

1 - головка блока до переобладнання з встановленою дизельною форсункою; 2 - головка блока після переобладнання з демонтованою дизельною форсункою та встановленою свічкою запалення;

Рисунок 4 - Дизельний двигун Д21А1 з демонтованими головками блока (а) та переобладнані 3 дизельного палива на газове паливо головки блока ГРМ (б)

На експериментальний дизельний двигун була також змонтована газова редукторна система живлення та мікропроцесорна система запалення власної розробки. Переобладнана 3 дизельного палива на газове паливо система живлення двигуна Д21А1 зображена на рис. 5.

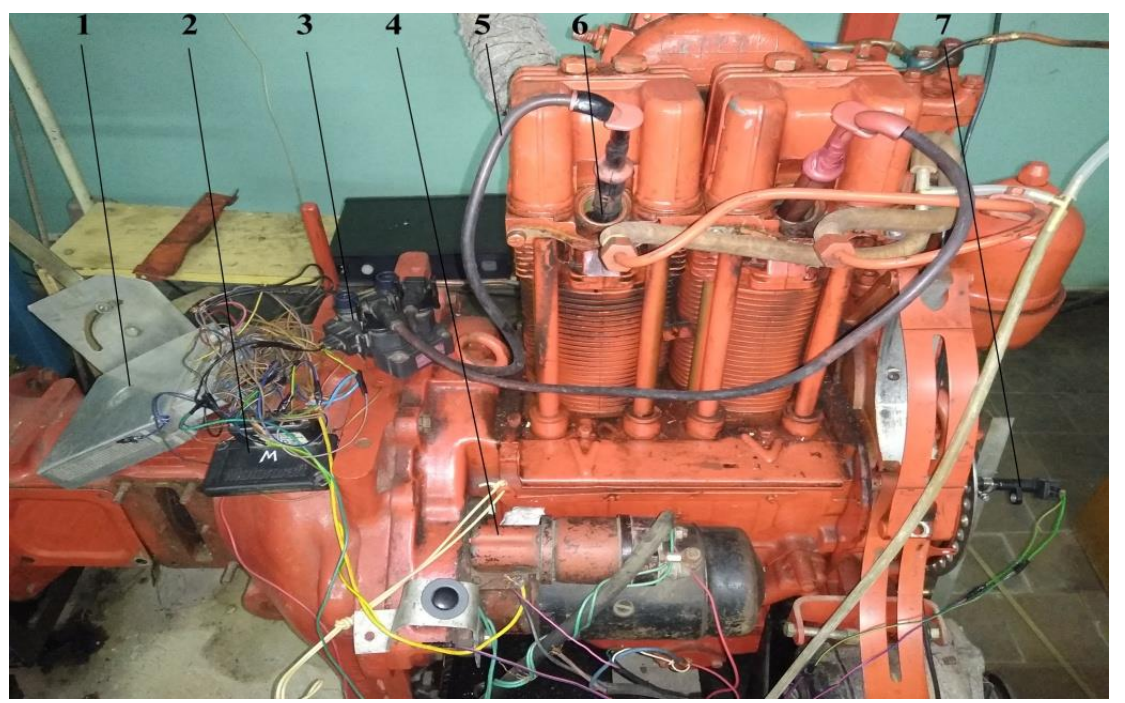

1 - електронний блок управління; 2 - комутатор системи запалення; 3 - модуль запалення; 4 електродвигун; 5 - високовольтні дроти; 6 - свічки запалення; 7 - датчик положення колінвалу Рисунок 5 - Переобладнана 3 дизельного палива на газове паливо система живлення двигуна Д21A1

Розроблена оригінальна електронна система запалення складається з блоку управління 1 (рис. 4), який змінює кут випередження запалення в залежності від режиму роботи двигуна, комутатора 2 , модуля запалення 3 , високовольтних дротів 4 та свічок запалення 5. Паливна суміш для живлення переобладнаного двигуна складалась 3 спиртогазової суміші, який подавався 3 конвектора. Маса витраченого дизпалива визначалась за допомогою електронної ваги. Для вимірювання об'ємної витрати та тиску відпрацьованих газів використовувались витратомір та манометр (рис. 6). Основні вимірювальні прилади та реєструвальна апаратура зображені на рис. 7. 


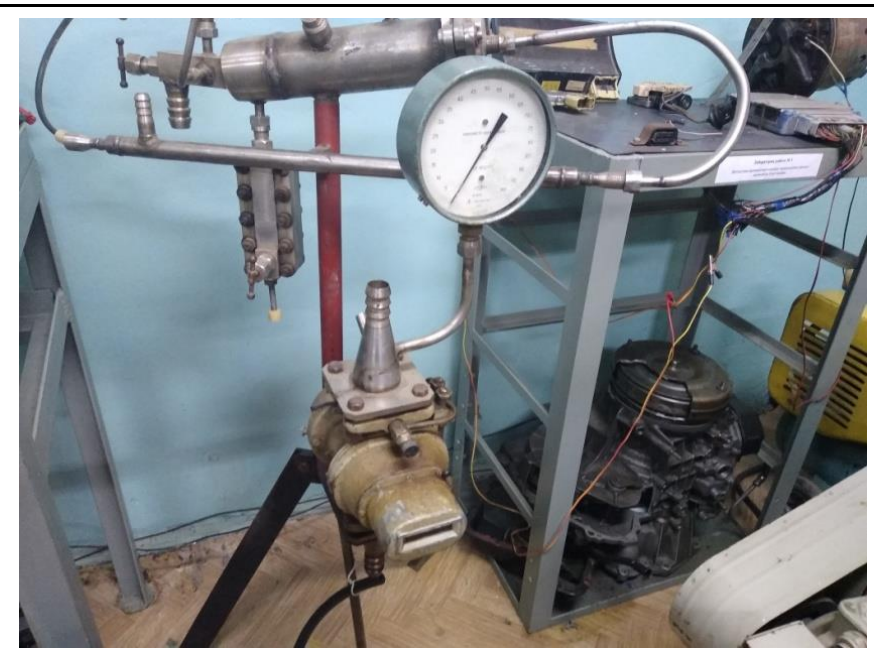

Рисунок 6 - Витратомір для вимірювання об’ємної витрати відпрацьованих газів та манометр для визначення тиску газу

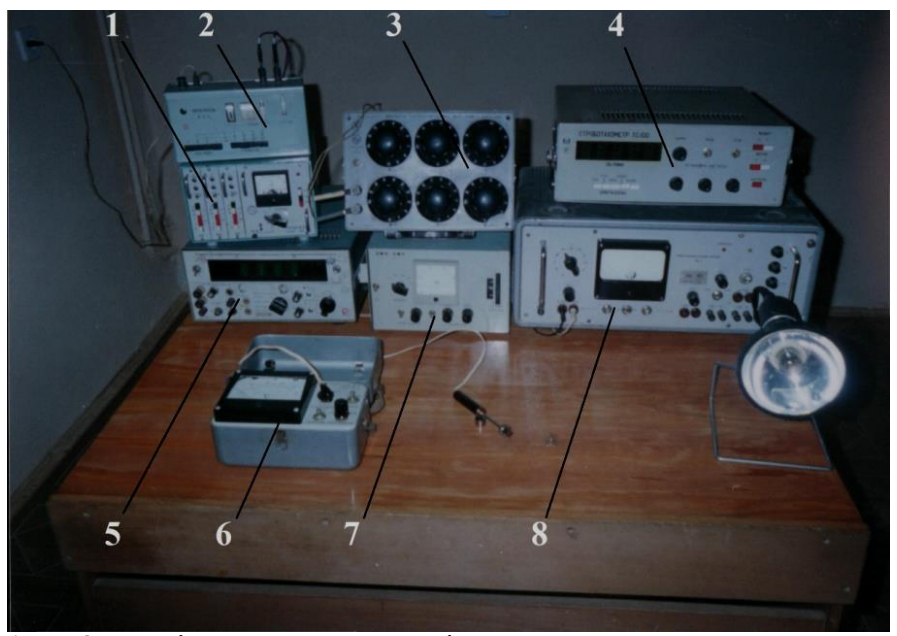

1 - підсилювач ПТ-4-01M; 2 - універсальний вимірювач RCL-3; 3 - магазин змінних опорів МСCP$60 \mathrm{M} ; 4$ - електронний строботахометр ТСт-100; 5 - цифровий вольтметр В7-20; 6 - амперметр ЕТП-

М; 7 - логометр УП-2А; 8 - універсальний блок живлення УІП-2

Рисунок 7 - Вимірювальні прилади та реєструюча апаратура

Результати експериментальних досліджень зміни температур пропонованої схеми енергозбереження в агрегатах трансмісії

Метою даних експериментальних випробувань було одержання функціональних залежностей впливу факторів навколишнього середовища i часу роботи на температуру оливи в механічній коробці передач при роботі без або з системою теплопостачання.

При проведенні експериментальних досліджень пропонованої схеми енергозбереження в агрегатах трансмісії за рахунок підігріву відпрацьованими газами відбувалось визначення зміни температур трансмісійної оливи та енергетичних втрат в трансмісії. Даний етап досліджень присвячено визначенню раціональних конструктивних параметрів елементів системи теплопостачання, розрахунок яких по ряду причин ускладнений, а також уточнення i перевірки розрахункових параметрів для розробки рекомендацій щодо підвищення ефективності роботи системи підігріву агрегатів трансмісії. Для ефективної роботи системи теплопостачання в перші хвилини роботи двигуна необхідно забезпечити максимальну передачу теплоти від відпрацьованих газів до трансмісійних агрегатів. Для виконання зазначеної задачі були проведені дослідження теплопередачі від відпрацьованих газів до трансмісійної оливи.

При визначенні теплового режиму роботи механічної коробки передач було встановлено, що температура навколишнього повітря значно впливає як на інтенсивність зміни температури трансмісійної оливи, так і на тривалість періоду виходу трансмісійного агрегату на стабільний температурний режим. Так встановлено (рис. 8), що при прокручуванні ведучого валу коробки передач на холостих оборотах $\left(800 \mathrm{xB}^{-1}\right)$ при температурі навколишнього середовища 263 К (мінус 10 $\left.{ }^{\circ} \mathrm{C}\right)$, температура оливи коробки передач підвищується за 140 хв. до $302 \mathrm{~K}\left(29^{\circ} \mathrm{C}\right)$. При прокручуванні ведучого валу коробки передач на холостих оборотах за той самий час від температур 275 К (плюс 2 $\left.{ }^{\circ} \mathrm{C}\right)$ і $283 \mathrm{~K}\left(\right.$ плюс $\left.10^{\circ} \mathrm{C}\right)$, температура оливи коробки передач підвищується, відповідно, до $308 \mathrm{~K}(35$ $\left.{ }^{\circ} \mathrm{C}\right)$ та $312 \mathrm{~K}\left(39{ }^{\circ} \mathrm{C}\right)$. Час нагріву для оптимального температурного режиму $30{ }^{\circ} \mathrm{C}$ трансмісійного агрегату при температурі навколишнього середовища $263 \mathrm{~K}$ (мінус $10^{\circ} \mathrm{C}$ ) складає 146 хв. 


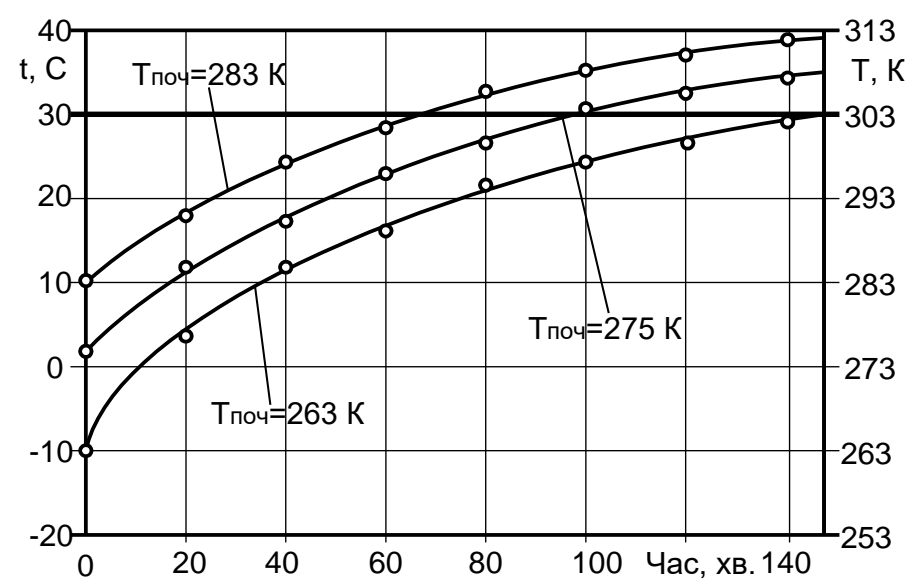

Рисунок 8 - Експериментальна залежність зміни температури мінеральної трансмісійної оливи в коробці перемикання передач

Визначення теплового режиму механічної коробки передач при різних швидкісних режимах відбувалося шляхом збільшення частоти обертання первинного валу коробки передач до $1000 \mathrm{xB}^{-1}$, 1200 хв$^{-1}, 1400 \mathrm{xв}^{-1}, 1600$ хв$^{-1}$. Результати випробування наведені на рис. 9.

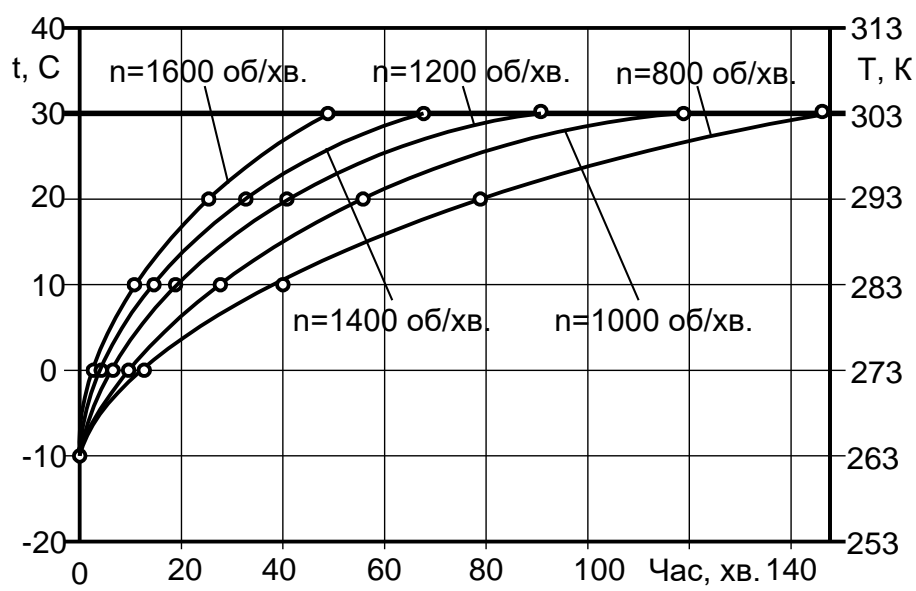

Рисунок 9 - Експериментальні залежності зміни температури мінеральної трансмісійної оливи в коробці перемикання передач при різних режимах обертання первинного валу коробки передач

3 графіка видно, що збільшення частоти обертання первинного валу механічної коробки передач призводить до значного підвищення температури іiі оливи. При цьому при частотах обертання первинного валу коробки передач $1000 \mathrm{xB}^{-1}, 1200 \mathrm{xB}^{-1}, 1400 \mathrm{xB}^{-1}, 1600 \mathrm{xB}^{-1}$ час нагрівання до оптимального температурного режиму $30{ }^{\circ} \mathrm{C}$ трансмісійного агрегату при температурі навколишнього середовища $263 \mathrm{~K}$ (мінус $10^{\circ} \mathrm{C}$ ) складає, відповідно, $118,91,68$ та 48 хв.

Результати експериментальних досліджень теплового стану коробки передач без підігрівання відпрацьованими газами (штатний режим існуючих підйомних установок) та 3 підігріванням відпрацьованими газами (пропонований режим удосконалених підйомних установок) зображені на рис. 10. 3 одержаних результатів випливає, що в штатному режимі існуючих підйомних установок оптимальна температура $30{ }^{\circ} \mathrm{C}$ досягається через 146 хв., а в пропонованому режимі удосконалених підйомних установок оптимальна температура $30{ }^{\circ} \mathrm{C}$ досягається через 34 хв., через 45 хвилин досягається температура $35^{\circ} \mathrm{C}$ і режим примусового підігріву вимикається. 


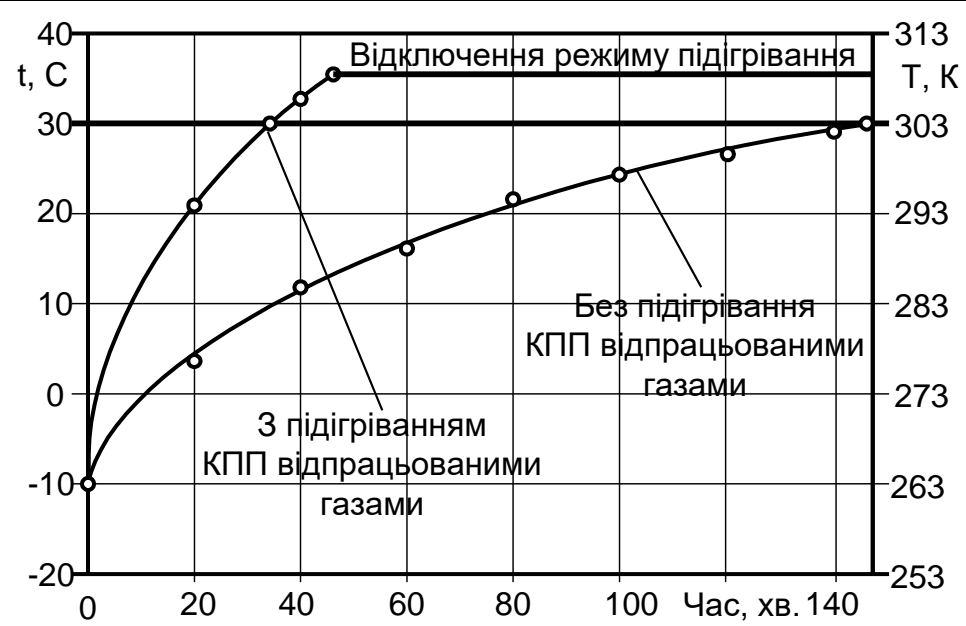

Рисунок 10 - Експериментальні залежності зміни температури мінеральної трансмісійної оливи в коробці перемикання передач при режимах обертання первинного валу КПП з/без підігрівання відпрацьованими газами

Під час досліджень було встановлено, що основними факторами, що впливають на тепловий стан механічної коробки перемикання передач при заданій частоті обертання, $\epsilon$ час роботи, температура відпрацьованих газів, температура оливи коробки передач. Крім того, було встановлено, що температура оливи в коробці передач в деяких випадках при роботі двигуна силового приводу на оборотах холостого ходу не досягає необхідного оптимального значення 313 K навіть після 3 годин роботи. Виходячи з цього, для підвищення температури оливи в механічній коробки перемикання передач використовується система підігріву відпрацьованими газами.

В процесі обробки експериментальних залежностей температури оливи в механічній КП від температури відпрацьованих газів і часу роботи спільно 3 системою теплопостачання (рис. 10) встановлено, що при роботі двигуна 3 мінімальною частотою обертання колінчастого вала на оборотах холостого ходу $\left(800 \mathrm{xB}^{-1}\right)$ температура навколишнього повітря значно впливає як на динаміку температури трансмісійного масла в механічною коробкою передач, так і на час нагрівання трансмісійної оливи до оптимальних температур 303-313 К.

Аналіз одержаних даних показує, що переданий від відпрацьованих газів середній тепловий потік за 30 хв. суттєво змінюється при збільшенні частоти обертання колінчастого вала від 800 до 1600 хв-1. Особливо в перші 20 хв. роботи спостерігається істотне підвищення значень передачі теплової енергії, а другий етап роботи (20-45 хв.) характеризується зниженням переданого теплового потоку. Це пов'язано з інтенсивністю збільшення температури оливи в коробці перемикання передач, при цьому середня різниця температур теплоносіїв зі збільшенням частоти обертання колінчастого вала змінюється в меншій мірі.

Аналіз отриманих даних показав, що зниження температури навколишнього середовища призводить до зниження динаміки температури оливи, причому можна стверджувати, що дана залежність має нелінійний характер. При цьому в міру прогрівання коробки передач вплив температури навколишнього повітря стає не таким значним. Одержані дані дозволяють також визначити необхідний час нагрівання оливи КП до оптимальних температур 303-313 К при зміні температури навколишнього середовища 3253 до 283 К.

Порівняльні випробування теплового стану коробки передач при роботі як 3 системою теплопостачання, так і без неї показали, що передана теплота впливає як на швидкість зміни температури, так і на час нагрівання температури оливи до оптимальних температур 303-313 К і виходу КПП на стабільний температурний режим.

Результати експериментальних досліджень зниження втрат енергії пропонованої схеми енергозбереження в агрегатах трансмісії за рахунок підігріву відпрацьованими газами

Дослідження втрат потужності з механічною коробкою передач включало в себе визначення загальних втрат (гідравлічних і механічних) на подолання сил опору обертання в залежності від температури трансмісійної оливи. Втрати в коробці перемикання передач автомобіля аналогічні витратам потужності, споживаної електродвигуном установки з врахуванням потужності механічних втрат, що втрачається в самому привідному двигуні. Для досліджень використовувалось дві марки найбільш використовуваних трансмісійних олив: мінеральна ТАп-15B SAE 80W-90 API GL-3 та напівсинтетична TM-5-18 SAE 75W90 API GL-5. Перша олива використовується в нафтогазовій промисловості України для трансмісій підйомних установок виробництва країн колишнього СНД, друга олива - для трансмісій підйомних установок виробництва США, Канади та країн Свропи.

В результаті дослідження було встановлено, що потужність, необхідна для прокручування коробки передач, при температурі навколишнього середовища 263 К в момент пуску двигуна для мінерального масла ТАп-15В склала 902 Вт, для напівсинтетичного ТМ-5-18 - 625 Вт (рис. 11). Подальше прокручування коробки передач при 273 К приводило до зниження витрат потужності, досягнувши 720 Вт для оливи ТАп-15В і 540 Вт для ТМ-5-18. При температурі оливи 303 К втрати 
потужності при використанні олив різних сортів практично зрівнялися і склали для мінеральної і напівсинтетичної оливи, відповідно, 448 і 425 Вт.

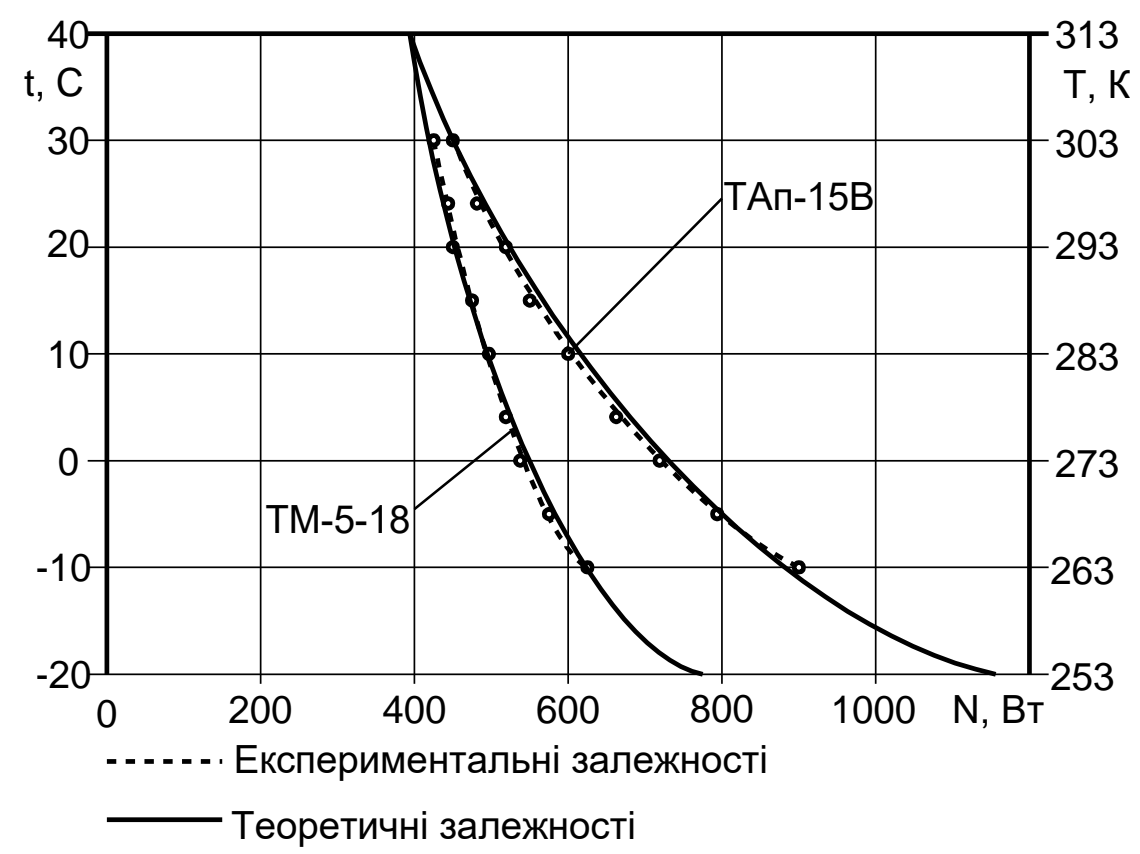

Рисунок 11 - Залежність втрат потужності в коробці перемикання передач в залежності від температури та сорту трансмісійної оливи

Для перевірки адекватності отриманої аналітичної моделі на рис. 11 були поміщені теоретичні залежності зміни втрат потужності в коробці перемикання передач від температури трансмісійної оливи. Поєднання теоретичних i експериментальних залежностей показало, що максимальна розбіжність щодо діапазону зміни втрат потужності від температури не перевищує 6 \%. Це свідчить про задовільну адекватності отриманої математичної моделі.

На підставі розробленої та підтвердженої математичної моделі для підйомної установки для ремонту свердловин УПА 60/80А на шасі КрАЗ-63221-04 (рис. 12) були проведені розрахунки для втрат потужності в коробці перемикання передач. Підйомна установка УПА 60/80А на шасі КрАЗ63221-04 може бути обладнана двигуном потужністю 176 кВт (240 к.с.) або двигуном потужністю 220 кВт (300 к.с.).

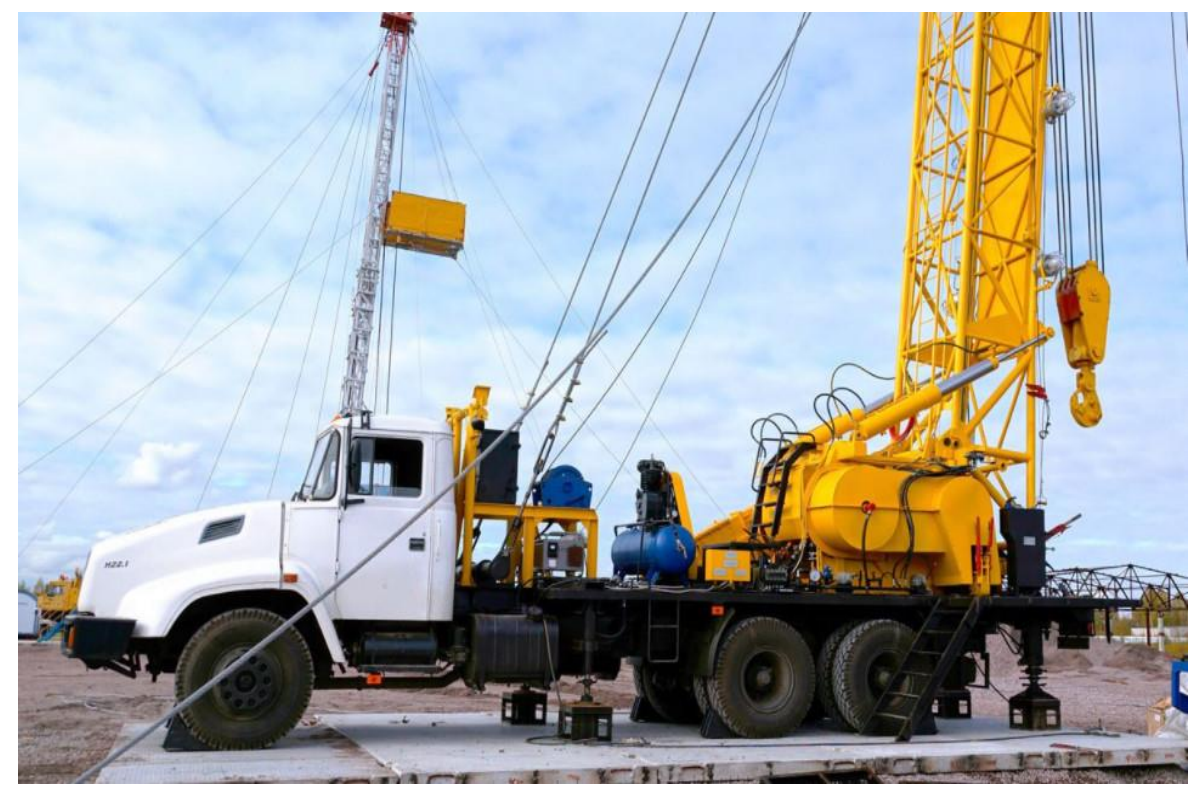

Рисунок 12 - Підйомна установка для ремонту свердловин моделі УПА 60/80А

В результаті дослідження було встановлено (рис. 13), що потужність, необхідна для прокручування коробки передач, при температурі навколишнього середовища 253 К в момент пуску двигуна для мінерального масла ТАп-15В складає 14,20 кВт, для напівсинтетичного ТМ-5-18 - 9,50 кВт. Подальше прокручування коробки передач при 273 К приводить до зниження витрат потужності, досягнувши 9,30 кВт для оливи ТАп-15В і 6,95 кВТ для ТМ-5-18. При температурі оливи 
( Криштопа С.І., Криштопа Л.І., Микитій І.М., Гнип М.М., Козак Ф.В. 2021

313 К втрати потужності при використанні олив різних сортів практично зрівнюються і складають для мінеральної і напівсинтетичної оливи, відповідно, 4,85 і 4,80 кВт.

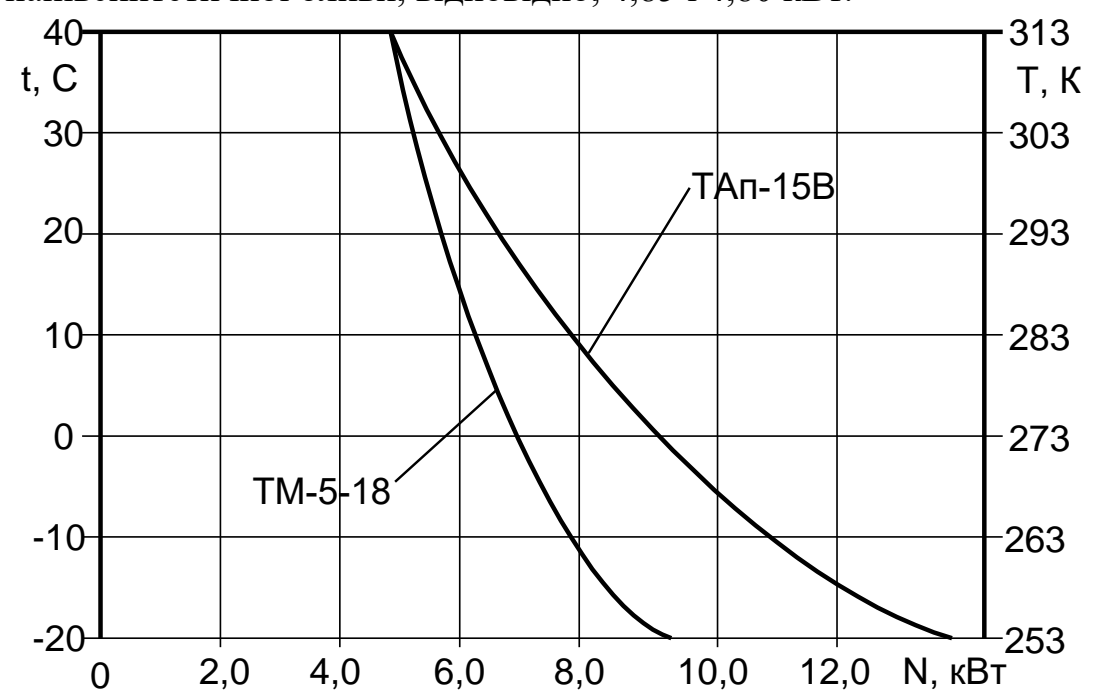

Рисунок 13 - Теоретична залежність втрат потужності в коробці перемикання передач підйомної установки моделі УПА 60/80А в залежності від температури та сорту трансмісійної оливи

Проведемо розрахунки перевитрат палива в коробці перемикання передач підйомної установки моделі УПА 60/80А з різними силовими приводами та за різних температур трансмісійної оливи (таб. 2).

Таблиця 2 - Результати розрахунків перевитрат палива в коробці перемикання передач підйомної установки моделі УПА 60/80А з різними силовими приводами та за різних температур трансмісійної оливи

\begin{tabular}{|c|c|c|c|c|c|c|}
\hline \multirow[t]{2}{*}{ Температура, К } & \multicolumn{2}{|c|}{$\begin{array}{c}\text { Витрати потужності в КПП, } \\
\text { кВт }\end{array}$} & \multicolumn{2}{|c|}{$\begin{array}{c}\text { Двигун / величини } \\
\text { мінімальної } \\
\text { ефективної питомої } \\
\text { витрати палива, } \\
\text { г/(кВт · год). }\end{array}$} & \multirow[t]{2}{*}{$\begin{array}{c}\text { Витрати } \\
\text { палива на } \\
\text { привід КПП, } \\
\text { напів- } \\
\text { синтетична } \\
\text { олива, кг/год. }\end{array}$} & \multirow[t]{2}{*}{$\begin{array}{c}\text { Витрати палива } \\
\text { на привід КПП, } \\
\text { мінеральна } \\
\text { олива, г/год. }\end{array}$} \\
\hline & $\begin{array}{c}\text { Напів- } \\
\text { синтетична } \\
\text { олива }\end{array}$ & $\begin{array}{l}\text { Мінеральна } \\
\text { олива }\end{array}$ & $\begin{array}{c}\text { ЯМЗ- } \\
\text { 238БЕ2 }\end{array}$ & $\begin{array}{c}\text { ЯM3- } \\
\text { 238BM }\end{array}$ & & \\
\hline 313 & 4,80 & 4,85 & \multirow{3}{*}{195} & \multirow{3}{*}{214} & $0,93-1,02$ & $0,94-1,04$ \\
\hline 273 & 6,95 & 9,30 & & & $1,36-1,49$ & $1,81-1,99$ \\
\hline 253 & 9,50 & 14,20 & & & $1,85-2,03$ & $2,77-3,03$ \\
\hline
\end{tabular}

На основних технологічних режимах, пов'язаних з бурінням та ремонтом свердловин можна прийняти середню питому витрату палива $220 \mathrm{r} /($ кВт · год). Величини мінімальної ефективної питомої витрати палива атмосферних двигунів ЯМЗ-238ВМ потужністю 176 кВт на оборотах колінчастого валу двигуна $1300 \mathrm{xB}^{-1}$ склали 214 г/(кВт · год); номінальної ефективної питомої витрати палива атмосферних двигунів ЯМЗ-238ВМ на оборотах колінчастого валу двигуна $2100 \mathrm{xв}^{-1}-259$ г/(кВт - год). Величини мінімальної ефективної питомої витрати палива наддувних двигунів ЯМЗ238БЕ2 потужністю $220 \mathrm{kBт} \mathrm{на} \mathrm{оборотах} \mathrm{колінчастого} \mathrm{валу} \mathrm{двигуна} 1400 \mathrm{xB}^{-1}$ дорівнювали 195 г/(кВТ · год); номінальної ефективної питомої витрати палива наддувних двигунів ЯМЗ-238БЕ2 на оборотах колінчастого валу двигуна $2100 \mathrm{xB}^{-1}-238$ г/(кВт ' год).

\section{ОБГОВОРЕННЯ РЕЗУЛЬТАТІВ ДОСЛІДЖЕННЯ}

Проведені дослідження показали, що зниження витрат енергії в трансмісіях підйомних установок для ремонту свердловин шляхом використання теплоти відпрацьованих газів для забезпечення швидкого прогрівання трансмісійних агрегатів та підтримування оптимального теплового режиму є досить вигідним.

В результаті розрахунків було встановлено, що перевитрата палива, необхідна для прокручування коробки передач підйомної установки моделі УПА 60/80А 3 різними силовими приводами, при температурі навколишнього середовища 253 К в момент пуску для мінерального масла ТАп-15В складає 1,83-1,99 кг, для напівсинтетичного ТМ-5-18 - 0,92-1,01 кг у порівнянні 3 температурою 313 К. Подальше прокручування коробки передач при 273 К приводить до зниження витрат палива, досягнувши 0,87-0,95 кг для оливи ТАп-15В і 0,43-0,47 кг для ТМ-5-18 у порівнянні 3 температурою $313 \mathrm{~K}$. 
Отже, аналіз одержаних експериментальних даних показав, що високу ефективність теплопередачі до агрегатів трансмісії та зниження витрат енергії в трансмісії можна досягти за рахунок різниць температур відпрацьованих газів i трансмісійної оливи. Суттєвим стимулом подальшого розвитку подібних систем $\epsilon$ те, що вони обумовлюють можливість сукупного вдосконалення характеристик транспортного засобу за комплексом показників. Їх реалізація на транспортних засобах дозволяє утилізувати відхідну теплову енергію та знижувати витрати палива нафтогазовим технологічним транспортом.

\section{ВИСНОВКИ}

Отже, аналіз одержаних експериментальних даних показав, що високу ефективність теплопередачі до агрегатів трансмісії та зниження витрат енергії в трансмісії можна досягти за рахунок різниць температур відпрацьованих газів і трансмісійної оливи. Суттєвим стимулом подальшого розвитку подібних систем $\epsilon$ те, що вони обумовлюють можливість сукупного вдосконалення характеристик транспортного засобу за комплексом показників. Їх реалізація на транспортних засобах дозволяє утилізувати відхідну теплову енергію та знижувати витрати палива нафтогазовим технологічним транспортом.

\section{ПЕРЕЛІК ДЖЕРЕЛ ПОСИЛАННЯ}

1. Енергетична стратегія України на період до 2030 року / Схвалена розпорядженням КМУ 15 березня 2006 р. № 145. - Режим доступу: http://zakon2.rada.gov.ua/laws/show/145-2006-p

2. Енергозбереження. Системи енергетичного менеджменту. Вимоги та настанова щодо використання: ДСТУ ISO 50001:2014. - К.: Мінекономрозвитку України, 2014. 26 с.

3. Шевцов В.М. Теоретичне дослідження безступінчастої трансмісії автомобіля КрАЗ 63221-02 для ремонту нафтогазових свердловин. / О.О. Островерх, А.П. Кожушко, В.М. Шевцов // Вісник Національного технічного університету "ХПІ". - Харків: НТУ "ХПІ". - 2017. - №6 (1228). - С. 45 51.

4. Денисюк С.П. Формування політики підвищення енергетичної ефективності - сучасні виклики та європейські орієнтири. Енергетика: економіка, технології, екологія. 2013. № 2. С. 7-22

5. Вирвінський П.П., Хоменко В.Л. Ремонт свердловин: Навчальний посібник. - Дніпропетровськ: Національний гірничий університет, 2003. - 219 с.

6. Бухаленко Е.И. Нефтепромысловое оборудование. Справочник. Москва: Недра, 1990.

7. Samorodov V. B., Ostroverch A. O., Kozhushko A. P. Development and analysis of stepless twoflow hydrostatic-mechanical transmission by criterion of greatest efficiency for cars used to repair oil and gas wells. Visnyk Natsional'nogo tekhnichnogo universytetu «KhPI» [The bulletin of the National Technical University "KhPI"]. 2012, vol. 60, pp. 105-111.

8. Samorodov V. B., Ostroverch A. O., Kozhushko A. P. Analysis of the technological mode of operation of a continuous hydrovolume-mechanical transmission using native hydro-units of a car used to repair oil and gas wells]. Visnyk Natsional'nogo tekhnichnogo universytetu «KhPI» [The bulletin of the National Technical University "KhPI"]. 2013, vol. 30, pp. 23-31.

9. Разяпов М.М. Повышение работоспособности агрегатов трансмиссии автотракторной техники в условиях низких температур: автореф. дис. ... канд. техн. наук / М.М. Разяпов. - Уфа, 2013. $-16 \mathrm{c}$.

10.Пустозеров Ю.И. Исследование эксплуатационных режимов работы трансмиссии трактора ДТ-75 в условиях низких температур: автореф. дис. канд. техн. наук /Ю.И. Пустозеров Новосибирск, 2003. - 23с.

11.Селиванов Н.И. Повышение эффективности работы тракторных агрегатов в зимних условиях АПК Восточной Сибири: автореф. дис. ... д-ра техн. наук / Н.И. Селиванов. - Красноярск, 2006.

12.Карпов П. М. Повышение топливной экономичности сельскохозяйственных тракторов в зимних условиях путем улучшения режимов смазки трансмиссий (на примере трактора ДТ-75М): автореф. дис. ... канд. техн. наук / П.М. Карпов. - Ульяновск, 1988. - 25 с.

13.Кутлин А.А. Исследование влияния режима движения автомобилей на температуру их основных агрегатов и расход топлива в зимних условиях эксплуатации: автореф. дис. ... канд. техн. наук / А.А. Кутлин. - Киев, 1981. - 20 с.

14.Разяпов М.М. Повышение работоспособности агрегатов трансмиссии автотракторной техники в условиях низких температур: автореф. дис. ... канд. техн. наук / М.М. Разяпов. - Уфа, 2013. $-16 \mathrm{c}$.

\section{REFERENCES}

1. Enerhetychna stratehiia Ukrainy na period do $2030 \mathrm{roku} /$ Skhvalena rozporiadzhenniam KMU 15 bereznia 2006 r. № 145. - Rezhym dostupu: http://zakon2.rada.gov.ua/laws/show/145-2006-r

2. Enerhozberezhennia. Systemy enerhetychnoho menedzhmentu. Vymohy ta nastanova shchodo vykorystannia: DSTU ISO 50001:2014. - K.: Minekonomrozvytku Ukrainy, 2014. 26 s.

3. Shevtsov V.M. Teoretychne doslidzhennia bezstupinchastoi transmisii avtomobilia KrAZ 63221-02 dlia remontu naftohazovykh sverdlovyn. / O.O. Ostroverkh, A.P. Kozhushko, V.M. Shevtsov // Visnyk Natsionalnoho tekhnichnoho universytetu "KhPI". - Kharkiv: NTU "KhPI". - 2017. - №6 (1228). - S. 45 51 . 
4. Denysiuk S.P. Formuvannia polityky pidvyshchennia enerhetychnoi efektyvnosti - suchasni vyklyky ta yevropeiski oriientyry. Enerhetyka: ekonomika, tekhnolohii, ekolohiia. 2013. № 2. S. 7-22

5. Vyrvinskyi P.P., Khomenko V.L. Remont sverdlovyn: Navchalnyi posibnyk. - Dnipro-petrovsk: Natsionalnyi hirnychyi universytet, 2003. - 219 s.

6. Bukhalenko E.Y. Neftepromyslovoe oborudovanye. Spravochnyk. Moskva: Nedra, 1990.

7. Samorodov V. B., Ostroverch A. O., Kozhushko A. P. Development and analysis of stepless twoflow hydrostatic-mechanical transmission by criterion of greatest efficiency for cars used to repair oil and gas wells. Visnyk Natsionalnogo tekhnichnogo universytetu «KhPI» [The bulletin of the National Technical University "KhPI"]. 2012, vol. 60, pp. 105-111.

8. Samorodov V. B., Ostroverch A. O., Kozhushko A. P. Analysis of the technological mode of operation of a continuous hydrovolume-mechanical transmission using native hydro-units of a car used to repair oil and gas wells]. Visnyk Natsionalnogo tekhnichnogo universytetu «KhPI» [The bulletin of the National Technical University "KhPI"]. 2013, vol. 30, pp. 23-31.

9. Raziapov M.M. Povyshenye rabotosposobnosty ahrehatov transmyssyy avtotraktornoi tekhnyky v uslovyiakh nyzkykh temperatur: avtoref. dys. ... kand. tekhn. nauk / M.M. Raziapov. - Ufa, 2013. - 16 s.

10.Pustozerov Yu.Y. Yssledovanye эkspluatatsyonnykh rezhymov raboty transmyssyy traktora DT-75 v uslovyiakh nyzkykh temperatur: avtoref. dys. kand. tekhn. nauk /Iu.Y. Pustozerov - Novosybyrsk, 2003. 23 s.

11.Selyvanov N.Y. Povyshenye effektyvnosty raboty traktornykh ahrehatov v zymnykh uslovyiakh APK Vostochnoi Sybyry: avtoref. dys. ... d-ra tekhn. nauk / N.Y. Selyvanov. - Krasnoiarsk, 2006.

12.Karpov P. M. Povyshenye toplyvnoi эkonomychnosty selskokhoziaistvennykh traktorov v zymnykh uslovyiakh putem uluchshenyia rezhymov smazky transmyssyi (na prymere traktora DT-75M): avtoref. dys. ... kand. tekhn. nauk / P.M. Karpov. - Ulianovsk, 1988. - 25 s.

13. Kutlyn A.A. Yssledovanye vlyianyia rezhyma dvyzhenyia avtomobylei na temperaturu ykh osnovnykh ahrehatov y raskhod toplyva v zymnykh uslovyiakh ekspluatatsyy: avtoref. dys. ... kand. tekhn. nauk / A.A. Kutlyn. - Kyev, 1981. - $20 \mathrm{~s}$.

14.Raziapov M.M. Povyshenye rabotosposobnosty ahrehatov transmyssyy avtotraktornoi tekhnyky v uslovyiakh nyzkykh temperatur: avtoref. dys. ... kand. tekhn. nauk / M.M. Raziapov. - Ufa, 2013. - 16 s.

Kryshtopa Sviatoslav, Kryshtopa Liudmyla, Ivan Mykytii, Hnyp Mariia, Kozak Fedir. Experimental researches of reduction of energy losses in transmission units lifting installations for well repair

The article is aimed at solving the problem of reducing energy losses in transmission units of lifting installations for well repair. The main directions for reducing the energy consumption of hoists for repairing wells were analyzed. The analysis of features of a design of transmissions of lifting installations for repair of wells is carried out. Studies of viscosity-temperature characteristics of modern transmission oils and temperature regime in transmission units have been performed. A method of rapid heating and maintaining the optimal temperature in the transmission units of lifting units by using the heat of the exhaust gases was proposed. A typical mechanical transmission of a hoisting installation for repairing wells on a wheeled chassis has been studied. The technique and means of experimental researches of energy efficiency of transmissions of lifting installations are resulted. Experimental studies of the implementation of the proposed method of reducing energy losses in transmission units. The dependence of the change in the temperature of the transmission oil in the gearbox at different modes of rotation of the primary shaft of the gearbox. The optimum thermal mode of operation of units of mechanical transmission of lifting installations by the manufacturer is not established in rigid frameworks. The determining factor is the efficiency of the oil under certain conditions. The dependence of power losses in the gearbox of the lifting unit of the UPA 60 / 80A model depending on the temperature and grade of transmission oil is obtained. The results of calculations of fuel consumption in the gearbox of the lifting unit of the UPA 60 / 80A model with different power drives and at different temperatures of transmission oil are given.

Key words: lifting installation for well repair, oil and gas technological transport; diesel engine; transmission unit; gearbox; heat utilization; exhaust gases; power; specific fuel consumption.

КРИШТОПА Святослав Ігорович, доктор технічних наук, професор, завкафедрою автомобільного транспорту, Івано-Франківський національний технічний університет нафти і газу,

E-mail: auto.ifntung@ukr.net, ORCID: http://orcid.org/0000-0001-7899-8817

КРИШТОПА Людмила Іванівна, кандидат технічних наук, доцент, доцент кафедри автомобільного транспорту, Івано-Франківський національний технічний університет нафти і газу, Еmail: 1.i.kryshtopa@mail.ru, ORCID: http://orcid.org/0000-0002-5274-0217

МИКИТІЙ Іван Михайлович, аспірант, кафедра автомобільного транспорту, Івано-Франківський національний технічний університет нафти і газу, E-mail: 7ivan1@i.ua, ORCID: https://orcid.org/0000$\underline{0002-8925-6349}$

ГНИП Марія Михайлівна, доктор філософії, асистент кафедри автомобільного транспорту, Івано-Франківський національний технічний університет нафти i газу, E-mail: marichka_gnip@ukr.net, ORCID: http://orcid.org/0000-0003-3662-0941 
КОЗАК Федір Васильович, кандидат технічних наук, професор, професор кафедри автомобільного транспорту, Івано-Франківський національний технічний університет нафти і газу, Еmail: auto.ifntung@ukr.net, ORCID: http://orcid.org/0000-0002-9147-883X

Sviatoslav KRYSHTOPA, Doctor of Technical Sciences, Professor, Head of Department of Automobile Transport, Ivano-Frankivsk National Technical University of Oil and Gas, E-mail: auto.ifntung@ukr.net, ORCID: http://orcid.org/0000-0001-7899-8817

Liudmyla KRYSHTOPA, PhD, Associate Professor, Department of Automobile Transport, IvanoFrankivsk National Technical University of Oil and Gas, E-mail: 1.i.kryshtopa@mail.ru, ORCID: http://orcid.org/0000-0002-5274-0217

Ivan MYKYTII, Postgraduate student, Department of Automobile Transport, Ivano-Frankivsk National Technical University of Oil and Gas, E-mail: 7ivan1@i.ua, ORCID: https://orcid.org/0000-0002-8925-6349

Mariia HNYP, Postgraduate student, Department of Automobile Transport, Ivano-Frankivsk National Technical University of Oil and Gas, E-mail: marichka_gnip@ukr.net, ORCID: http://orcid.org/0000-0003$\underline{3662-0941}$

Fedir KOZAK, PhD, Professor, Department of Automobile Transport, Ivano-Frankivsk National Technical University of Oil and Gas, E-mail: auto.ifntung@ukr.net, ORCID: http://orcid.org/0000-00029147-883X

DOI 10.36910/automash.v2i17.638 